\title{
THE CRITERION OF ETHICS AN OBJECTIVE REALITY.
}

\section{TWO DEFINITIONS OF GOOD.}

W HILE Mr. Herbert Spencer in his "Data of Ethics" may be considered as the most persuasive and popular, Prof. Harald Höffding, it appears to me, is the most scholarly and learned expounder of that ethical theory which bases morality upon the principle of the greatest happiness for the greatest number. The Monist No. I contained (pp. I39-I4I) a criticism of Professor Höfding's work on Ethics, and Professor Höffding's article in this number is in part a further exposition of his views, and in part an answer to the criticism of The Monist.

Professor Höfding proposes, as pointed out in the criticism of The Monist, two criteria of ethics, (I) that which promotes the lifetotality, and (2) that which produces a continuous and permanent state of pleasurable feelings. These two criteria happen to come in conflict. John Stuart Mill calls attention to the fact that a well fed pig is more satisfied than man and a jolly fool is happier than Socrates. When Professor Höffding considers the state of man preferable to that of a pig, while granting that the latter, and not the former, enjoys a continuous state of pleasurable feelings, when he similarly prefers the doleful disposition of a sombre philosopher to the empty merriness of a happy fool, he does in my opinion unquestionably surrender the second criterion in favor of the first.

Professor Höfding's present explanation of the subject does not satisfy me. The main point of my criticism, it seems to me, has not been answered, and the difficulty is not overcome. Professor 
Hoffding declares that the strong desire for activity, development, and progress does not exist at all stages. It is itself a consequence of development and progress (p. 537). This, it may be granted, explains why a civilised society cannot help developing workers that plod and toil, finding no satisfaction unless they plod and toil; but it does not explain why (if after all the criterion of our ethical judgment remains happiness or the continuous state of pleasurable feelings) their state is preferable to that of indolent and happy savages.

Professor Höffding says :

"If it could be proved that increasing pain followed necessarily on all advancement of civilisation . . . . in that case it would be impossible to combine civilisation and welfare" (i. e. a continuous state of pleasurable feelings).

Well, if that be so,-as Professor Höffding himself in the comparison of man to a pig and of Socrates to a fool has actually conceded to be true, - if we stand between the dilemma of civilisation and welfare, or in other words if we have the choice only between a higher stage of life and a happier state of existence, which is preferable? That which Professor Höfding considers as preferable is his true criterion of what he calls good. The other one holds only so long as it agrees with his true and final criterion, so long as it does not come in conflict with it.

Suppose we select as the final criterion of ethics not the growth and development of the life-totality, but that of procuring to the greatest number of men, as much as possible, a continuous state of pleasurable feelings, - what will be the outcome of it? Can we suppose that, if these two principles collide, we shall be able to stcp growth? Can we expect to overcome nature and to curtail natural evolution so as to bring about a more favorable balance between our pleasures and pains? If we do, we shall soon find out that we have reckoned without our host.

A conflict between civilisation and welfare, (i. e. between natural evolution and our pleasurable feelings,) would not discontinue civilisation as Professor Höffding supposes, it would rather produce a change in what we have to consider as welfare. We have to be pleased with the development of our race according to the laws of nature, and those who are displeased might just as well commit 
suicide at once, for they will go to the wall, they will disappear from the stage of life. Those alone will survive who are pleased with that which the laws of nature demand.

Our pleasurable feelings are subjective, nature and the laws of evolution are objective. The criterion of ethics is not subjective but objective. The question is not what produces pleasurable feelings, but what is the unalterable order of the world with which we have to be pleased.

The question of ethics, in my mind, is not what we wish to do or what we think we ought to do, but what we must do. Nature prescribes a definite course. If we choose another one, we shall not reach our aim, and if we reach it, it will be for a short time only.

The aim of nature is not the happiness of living beings, the aim of nature, in the realm of organised life, is growth, development, evolution. Pleasures and pains are phases in the household of life, they are not life's aim. Experience shows that in reaching a higher stage we acquire an additional sensibility for both, for new pleasures and new pains. The pleasures of human existence in comparison with those of animals have been as much intensified and increased as the pains. The ratio has on the average remained about the same and it has rarely risen in favor of pleasures. Rather the reverse takes place : the higher man loses the taste of enjoying himself without losing the sensitiveness of pain.

Ethics, as a science and from the standpoint of positivism, has to inquire what according to the nature of things we must do. It has to study facts and from facts it has to derive rules (the moral prescripts) which will assist us in doing at once what we shall after all have to do. The criterion of ethics is not some standard which we put up ourselves, the criterion of ethics is agreement with facts.

\section{THE AUTHORITY OF MORAL COMMANDS.}

Professor Höffding emphasises " the fact that there is not merely one single ethical problem but many"-a fact which cannot be denied, for there are, indeed, innumerable problems of an ethical nature. However, we must bear in mind that all the ethical problems are closely interconnected. The better we understand them, the 
more shall we recognise that all together form one great system of problems, and that one problem lies at the bottom of all. This one basic problem I have called the ethical problem.

The solution of the basic problem of ethics will not involve the ready solution of all the rest, but we can be sure that it will throw light upon any question that is of an ethical nature.

Professor Höffding recognises the importance of system in ethics. He says :

"The systematism of ethical science is still so little advanced that it is necessary to draw out a general outline before we pass on to any single feature. The value of systematism is namely this, that we are immediately enabled to see the connection of the single questions with one another as well as their distinctive peculiarity."

It appears almost unfair toward the present state of ethical science when Professor Höffding adds :

"In ethics we are not yet so far advanced."

If we were not, we should do our best to advance so as to recognise the unity of all ethical problems. We must first recognise the ethical problem, before we can with any hope of success approach the many, which are dependent upon the one.

Which is the one basic problem of ethics?

We read in Matthew, xxi. 23 :

"And when Jesus was come into the temple, the chief priests and the elders of the people came unto him as he was teaching and said, By what authority doest thou these things? and who gave thee this authority ?"

This question is legitimate and all our ethical conceptions must necessarily depend upon the answer which we accept as satisfactory. The basic problem of ethics is the foundation of ethics, it is the justification of the ethical prescripts, it is the discovery of the authority upon which ethical rules are based. If there were no power that enforces a certain line of conduct, ethics in my opinion would have no right of existence; and if any one preaches certain commands, he is bound to give sațisfactory reasons why we must obey his commands.

Professor Höffding says that ethics "starts from its own assumptions" (p. III). Ethics should not start from any assumptions. 
If we are to come to a mutual understanding we must drop all subjectivism, we must not study ethics from special points of view, from the principles or standards of any individual or group of individuals. There is not the slightest use of a person making himself any "highest and only aim" which, it may be true, "from his point of view can never be refuted." So long as ethics starts from assumptions or principles, it will be no science; for truly, as Professor Höffding says in excuse of the inability to prove principles, "The difficulty always occurs in the enunciation of a principle that a direct demonstration of its validity cannot be given."

The requirement of ethics is to arrive at statements of fact. Let us build upon facts and we shall stand upon solid ground.

Ethics in order to be scientific must be based upon the objective and unalterable order of things, upon the ascertainable data of experience, upon the laws of nature.

\section{Professor Höffding says :}

"Religious ethics is founded on authority. Its contcnts are the revealed commands of authority; the feeling which impels us to pass ethical jutgments is the fear or reverence or love with which men are filled in the presence of divine authority."

Scientific ethics can in this respect not be different from religious ethics, for it is also based upon authority. A scientific ethicist has to proceed like any other naturalist; he must observe the course of events and attempt to discover the laws in accordance with which the events take place. These laws are no less unalterable than any other natural laws, and we may appropriately call them the natural laws of ethics. The moral commands of ethical teachers have been derived, either instinctively or with a clear scientific insight, from the natural laws of ethics. The authority of the natural laws of ethics has been decked out by different religious teachers with more or less mythological tinsel or wrapped in mystic darkness; for practical purposes it remained to some limited extent the same and will to some extent always remain the same, for we shall have to obey the moral law, be it from fear, or reverence, or love.

The unity of all the ethical problems will be preserved, however much they may be differentiated. Indeed Professor Höffding in his 
enumeration sufficiently indicates their interconnection. He speaks of (I) the motive principle of judgment, (2) the test-principle of judgment, and (3) of the motive to action. Whatever difference he makes between these three terms, it is obvious that whether and how far judgments, tests, or motives are sound will depend upon their agreement with the authority of the natural law of ethics. The pedagogic problem is also connected with the ethical problem because upon our solution of the latter will directly depend the aim and indirectly also the method of education. Such complex motives as "ambition or the instinct of acquisition" will become " the means of attaining to true ethical self-assertion" in the degree proportional to the elements they contain which will strengthen our efforts of setting us at one with the natural law of ethics.

To sum up: The natural law of ethics has to be derived from facts like all other natural laws. The natural law of ethics is the authority upon which all moral commands are based, and agreement with the natural law of ethics is the final criterion of ethics.

\section{ETHICS AND WELFARE.}

I have no objection to an ethics of welfare; on the contrary, I consider every ethics as an ethics of welfare. My objection to Professor Höffding's ethics is solely directed against his definition of welfare as "a continuous state of pleasurable feelings." Welfare is according to my terminology that state of things which is in accord with the natural law of ethics, and it so happens that welfare must as a rule not only be bought, but also constantly maintained with many pains, troubles, anxieties, and sacrifices. It is true that upon the whole there may be a surplus of happiness and of satisfaction, if not of pleasures; but the surplus of happiness (important though it is) does not constitute that which is morally good in welfare Morally good (the characteristic feature of the ethical idea of welfare) is that which is in accord with the natural law of ethics.

If the term "utility" were defined by Utilitarians in the sense in which I define welfare, I should also have no objection to utilitarianism. The Utilitarians, however, define their theory as "the 
Greatest Happiness Principle," and if "useful" is taken in its ordinary sense as that which is profitable or advantageous, it makes of utilitarianism an ethics of expediency.

\section{FEELINGS AND JUDGMENTS.}

The fundamental difference between Professor Höffding and myself, and as it seems to me his $\pi \rho \tilde{e} \tau o \nu \psi \psi \varepsilon \tilde{v} \delta o 5$, lies in his definition of ethical judgments. He says :

"Ethical judgments, judgments concerning good and bad, in their simplest form are expressions of feeling, and never lose that character however much influence clear and reasoned knowledge may acquire with respect to them.

I am very well aware of the fact that all thinking beings are first feeling beings. Thought cannot develop in the absence of feeling. Without feeling there is no thought; but thought is not feeling, and feeling is not thought.* By thought I understand the operations that take place among representative feelings, and the essential feature of these feelings is not whether they are pleasurable or painful, but that they are correct representations. Judgments. are perhaps the most important mental operations. There are logical judgments, legal judgments, ethical judgments, etc. In none of them is the feeling element of mental activity of any account. That which makes of them judgments is the reasoning or the thoughtactivity. Whether a judgment is correct or not does not depend upon the feeling that may be associated with it, but it depends upon the truth of its several ideas and the propriety of their connection.

A judgment, be it logical, juridical, ethical, or any other, is the more liable to be wrong, the more we allow the feeling element to play a part in it. Judgments swayed by strong feelings become biassed; they can attain to the ideal of truth only by an entire elimination of feeling. $\dagger$

* See the chapter "The Nature of Thought" in The Soul of Man, p. 354.

† Professor Höffding says: "The feeling of pleasure is the only psychological criterion of health and power of life." Every physician knows the insufficiency of this criterion. Many consumptives declare that they feel perfectly well even a few hours before their death. 
Ethics in which the feeling element is the main spring of action, is called sentimentalism. Sentimental ethics have no more right to exist than a sentimental logic or a sentimental jurisprudence.

The philosophy of Clärchen in "Egmont" appears to be very strong sentimentalism, and I do not believe that her demeanor can be set up as an example for imitation. Her love happiness is an intoxication. She vacillates between two extremes, now himmelhoch jauchzend and now zum Tode betrübt, and her life ends in insaniyt.

To consider ethical or any other judgments as feelings, and to explain their nature accordingly, seems to me no better than to speak of concepts as consisting of vowels and consonants, and to explain the nature of conceptual thought from the sounds of the letters. We cannot speak without uttering sounds, but the laws of speech or of grammar have nothing to do with sound and cannot be explained in terms of sound. When we think and judge, we are most assuredly feeling, but the feeling is of no account, and whether the feeling is pleasurable, or painful, or indifferent, has nothing to do whatever with the correctness or the ethical value of judgments.

\section{PLEASURE AND PAIN.}

It is very strange that, so far as I am aware, no ethicist who bases ethics upon the Happiness Principle has ever investigated the nature of pleasure and pain. It is generally assumed that pleasure is an indication of growth and pain of decay, but it has never been proved, and after a careful consideration of this theory I have come to the conclusion that it is based upon an error. Growth is rarely accompanied with pleasure and decay is mostly painless.

Optimistic philosophers look upon pleasure as positive and pain as negative, while the great pessimist Schopenhauer turns the tables and says pleasure is negative and pain positive.

An impartial consideration of the subject will show that both pleasure and pain are positive. Pain is felt whenever disturbances take place, pleasure is felt whenever wants are satisfied; and unsatisfied wants are perhaps the most prominent among the disturbances that produce pain.*

* See the chapter "Pleasure and Pain" in The Soul of Man, p. 338. 
Professor Höffding. says :

"I agree with Dr. Carus that "this world of ours is not a world suited to the taste of a pleasure-seeker," if we understand by pleasure passive sensual enjoyment; an enjoyment which is not united with the rest and nourishment with which not only an immediate pleasurable feeling is connected, but whereby power is also gathered for continued endeavor."

When I say that this world of ours is not a world suited to the taste of the pleasure-seeker, I do not restrict the meaning of pleasure to "passive sensual enjoyment," but to all kinds of pleasure. There are also intellectual and artistic voluptuaries who sacrifice anything, even the performance of duty, to their pleasure, which I grant is far superior to any kind of passive sensual enjoyment. The pursuit of pleasure is not wrong in itself ; but it is not ethical either. Ethics in my opinion has nothing to do either with my own pleasures or with the pleasures of anybody else. The object of ethics is the performance of duty; and the main duty of man is the performance of that which he needs must do according to the laws of nature, to let his soul grow and expand, and to develop to ever higher and nobler aims.

\section{PLEASURABLE FEELINGS AS AN ETHICAL CRITERION.}

I know of a French teacher who has an excellent French pronunciation and speaks with perfect accuracy, but whenever he is asked to give a rule which may serve as a guide and a help to correct grammer and elocution, he says : "The chief rule in French is euphony."- "Exactly! But the same rule holds good in a certain sense for all languages."-_"O no," he says, "the German is harsh and the English is tongue-breaking; only in French is the supreme law euphony."- "Now for instance," we venture to object, "you say la harpe. and not l'arpe; you pronounce the ai different in different words you say $j$ 'ai, but you say il fait and you have again a different pronunciation of the ai in nous faisons." He replies, "To pronounce $j a \hat{\imath}$, or as the Germans say chai would be barbarous. To say l'arpe, instead of la harpe is simply ridiculous."-_"The question is," we continued in our atten.pts to understand him, "what is euphonious to the ear of an educated Frenchman?"-_Well," he says, "the ear will tell you. That which jars on the ear is wrong. 
To say quat' instead of quatre, or vot' instead of votre, is wrong, it is vulgar. Why? it jars on the ear."

This method of teaching French appears to me a good illustration of our objection to the happiness principle of ethics. It is perfectly true that instances of immorality jar on the feelings of ethically trained minds. Why? They have become accustomed to them and look upon them as barbarous. Ungrammatical expressions and such pronunciations as do not agree with the spirit of a language are suppressed by those who recognise them as incongruous elements. Mistakes jar on their ears because they are incorrect, but they are not incorrect because they jar.

Oatmeal is a favorite dish among the Scotch. If you ask them why they eat it, they will most likely tell you, because it has an agreeable taste. But why do they like it? Because they have through generations grown accustomed to a dish which is conducive to health. Most of the dishes that are wholesome have an agreeable taste to a non-corrupted tongue. But agreeable taste for that reason cannot be considered as the supreme rule in selecting our menu. Agreeable taste is in cases of sickness a very unreliable guide and it is no criterion for a wholesome dinner. Surely the ethics of eating could not be based on agreeable taste.

The pleasurable feeling that is perceived in the satisfaction of hunger through appropriate food or in the satisfaction of any want, is not the bedrock of fact to which we can dig down; it is in itself a product of custom, of inherited habits, and other circumstances; and it can the less be used as a criterion because it varies greatly with the slightest change of its conditions.

Liberty is generally and rightly considered as a good, even though the slave may have and very often actually has enjoyed more happiness than the freed man. Stupidity is considered as an evil, although it inflicts no direct pains and may be the source of innumerable pleasures insipid in the view of others, but delightful to the jolly fool. Professor Höffing quotes from Waitz that the Indian does not progress because he "lives a happy life." Unhappiness is the cause of progress. We look down upon the Fuegians and upon the indolent South American tribe described by Humboldt. 
But have they not reached the ain of ethics, if happiness be that . aim? Professor Höffding says in explanation of their condition :

"That which would make such a life unendurable for us, the strong desire for activity, development, and progress, this desire does not exist at such stages."

If that is so, our strong desire for activity should be denounced as the source of evil. It would be ethical in that case, as some labor unions and trusts actually propose, to stop, or at least, to impede further progress. The attempt of the Jesuits in Paraguay, which to some extent was an unequivocal success, to rule the people through a spiritual dependence satisfying all their wants and keeping them in perfect contentment, cannot be condemned from that principle of welfare which defines welfare as a continuous state of pleasurable feelings.

I can see how a man can be induced to submit to a moment of pain in order to escape more pain in the future, but I cannot see on what ground one man can be requested to sacrifice himself to suffer pain or to forego his pleasures in order that a dozen or a hundred men may have a jolly time. It appears to me that a greater error has never been pronounced than that of making "the greatest happiness of the greatest number" the maxim of ethics.

For the same reason that prevents us from regarding the principle of happiness as the aim of ethics or as its test and criterion, we cannot consider self-humiliation, contrition, misery, and the abandonment of gayety and merriness as moral or meritorious. Joy and grief are in themselves as little wrong as they are virtuous. Any ethics the end of which is a morose austerity, simply because it makes life dreary, is at least as much mistaken as a philosophy which finds the purpose of life in mere pleasure, be it ever so vain, simply because it is pleasure. To pursue happiness or renounce it, either may sometimes be moral and sometimes immoral. Again, to undergo pain and to inflict pain on others, or to avoid pain, either may also be moral or immoral. The criterion of ethics will not be found in the sphere of feelings. Morality cannot be measured by and it cannot be expressed in pleasures ond pains. 


\section{THE SUPERINDIVIDUAL AND SOCIETY.}

Professor Höffding criticises my view of "that superindividual soul-life which we call society," as based upon a mystical personification of society.

The superindividual motives of the human soul as I use the term, are actual realities, they are no less actual and concrete than are the image and the concept of a tree in my brain. I have suffciently explained their origin and natural growth ("Ethical Problem," pp. 34-44), and feel that Professor Höffding's charge rests upon a misunderstanding. It appears to me that his term "sympathy," which he regards as the main element of ethical feelings leading to the adoption of the principle of general welfare, is much more liable to be interpreted in a mystical way. At least Schopenhauer's idea of sympathy (which he calls Mitleid) is undoubtedly a very mysterious thing, and its existence is supposed to be a direct manifestation of the metaphysical. I do not say that Professor Hoffding uses the word sympathy in the sense of Schopenhauer's idea of Mitleid, but $I$ am sure that if he attempts to explain its natural origin, he will (in order to remain positive and scientific) have to go over the same ground and arrive at the same conclusion as I did, although he may express himself in different words.

The truth is that man's ideas consist in representations of things and of relations without him, and these ideas are not the product of his individual exertions alone, they are the product of social work and of the common activity and intercourse of human society. This is true of language as a whole and of every single word which we use. This is true of all conceptual thought and most so of all ethical impulses. In spite of all individualism and in spite of the truth that lies in certain claims of individualism as to personal liberty and freedom of self-determination, I maintain that there is no individual in the sense of a separate ego-existence. That which makes of us human beings is the product of social life. I call the ideas and the impulses naturally developing in this way, superindividual, and if we could take them out of the soul of a man, he would cease to be a man. What is man but an incarnation of mankind! Social intercourse 
and common work produce the superindividual ideas and impulses in man, and these superindividual ideas and impulses in their action constitute the life of society.

This view is not "a mystical personification of society" under the simile of an organism, but it is a description of certain facts in the development of the human soul.

Society is not an aggregation of individuals, it is constituted by the superindividual element in the souls of individual men. The number of people in a society is for ethical purposes unessential. Professor Höffding accordingly makes an unimportant feature prominent, when he says:

"The idea of society, if it is to be scientifically employed, must always be so applied that at every point the definite group of individuals which it represents may be established."

If the greatest happiness of the greatest number among a definite group of individuals constitutes the morality of an act, would not the man who falls among thieves be under the moral obligation to renounce his property because the robbers constitute the majority?

If we leave the superindividual element out of sight, we shall naturally fall into the error of counting the individuals and deciding right and wrong by majority votes. The pleasure of a majority however does not constitute justice, and the greatest happiness of the greatest number is no criterion of that which is to be considered as morally good.

Society in the sense of a mere number of individuals will by and by create but does not constitute morality; nor can the majority of a society propose a criterion. The nature of moral goodness is not a matter of number nor of size nor of quantity. It must be sought in the quality of our ideas and motives. Moral are those ideas which tend to build up the life-totality of our souls so as to engender more and more of mankind in man, or still broader expressed, so as to keep man in harmony with the whole cosmos-with God.

VIII. THE POLICY OF THE ETHICAL SOCIETIES.

Professor Höffding considers it perfectly justified that the leaders of the ethical societies "keep these institutions as independent as possible not only of all dogmatic tendency of thought but also of 
all unnecessary philosophical hypotheses and speculations." So do we, for we object to dogmas, to hypotheses, and mere speculations. We consider the era of dogmatic religion as past, and trust in the rise of a religion based on truth, i. e. a natural and cosmical religion which stands on facts verifiable by science. Every religion, be it ever so adulterated by superstitions which as a rule, the less tenable they appear, are the more tenaciously defended as infallible dogmascontains in its world-conception at least the germ of becoming a cosmical religion. The development of all religions aims at one and the same goal, namely the recognition of the truth and the aspiration to live accordingly. Those religions which remain faithful to this spirit of the religious sentiment will survive; they will drop the errors of dogmatic belief, they will free themselves of the narrowness of sectarianism and develop the cosmic religion of truth-of that one and sole truth which need not shun the light of criticism and which is at one with science.

We do not object to the ethical societies that they have no dogmas and that they do not identify themselves with a special philosophy; we object solely to their proposition to preach ethics without having a religion, or without basing ethics upon a conception of the world. And why do we object? Simply because it is impossible to preach ethics without basing it upon a definite view of the world, for ethics is nothing more or less than the endeavor to act according to a certain conception, to realise it in deeds. Can you realise in deeds a conception without having any? Can you live the truth without knowing the truth? You must at least have an instinctive inkling of what the truth is.

Mr. Salter separates the domains of ethics and science. He does not believe that ethics can be established on science, for he declares that science deals with facts, i. e. that which is, while ethics deals with ideals, i. e. that which ought to be. "We have to believe in ethics if we believe in them at all," Mr. Salter says, "not because they have the fact on their side but because of their own intrinsic attractiveness and authority." * This reminds me of one

* What Can Ethics Do For Us, p. 5. By W. M. Salter. C. H. Kerr, Chicago, 1891. 
of Goethe and Schiller's Xenions in which the German poets critiicise the one-sided positions of enthusiasts (Schwärmer) and philistines:

Had you the power, enthusiasts, to grasp your ideals completely,

Certainly you would revere Nature. For that is her due.

Had you the power philistines, to grasp the total of Nature,

Surely your path would lead up to th' idea's domain.

Ideals have no value unless they agree with the objective worldorder which is ascertained through inquiry into the facts of nature. Ideals whose ultimate justification is intrinsic attractiveness and whose authority is professedly not founded on reality but on rapt visions of transcendental beauty, must be characterised as pure subjectivism. They are not ideals but dreams.

The ethical societies have as yet-so far as I am aware of-not given a clear and definite definition of good. Professor Adler treats this question with a certain slight. Concerning the facts of moral obligation he believes in "a general agreement among good men and women everywhere." (The italics are ours.) The Open Court (in No. I40) has challenged the Ethical Societies, saying that "we should be very much obliged to the Ethical Record, if it would give us a simple, plain, and unmistakable definition of what the leaders of the ethical movement understand by good, i. e. morally good." But this challenge remained unanswered.

It will appear that as soon as good is defined not in tautologies, ${ }^{*}$ but in definite and unmistakable terms, the conception of good will be the expression of a world-conception. Is it possible to do an act which is not expressive of an opinion? And if an act is not expressive of a clear opinion, it is based upon an instinctive, an unclear, and undefined opinion. When the ethical societies declare that they do not intend to commit themselves to religious or philosophical views, they establish an anarchy of ethical conviction. Religion, as we have defined it, is man's inmost and holiest conviction, in accord with which he regulates his conduct. The ethical societies im-

"It is obvious that such definitions as "good is that which produces welfare" are meaningless, so long as we are not told what it is that makes a certain state well faring or well being. 
plicitly declare that we can regulate our conduct without having any conviction.

Is not an ethical society without any definite convictions upon which to base its ethics like a ship without a compass in foggy weather?

The attitude of the ethical societies in not committing themselves to any religious or philosophical view is after all-mand how can it be otherwise?-a palpable self-delusion, for their whole policy bears unmistakably a definite and characteristic stamp. The leaders of the ethical-societies will most likely repudiate my interpretation of their position, because it appears to me that they are not clear themselves concerning the philosophical basis upon which they stand and thus (as I am fully aware) many contradictory features appear by the side of those which I should consider as most significant.

\section{PROFESSOR ADLER'S POSITION.}

Professor Adler is the founder of the Ethical Societies, he is their leader, and however much Mr. Salter, Dr. Coit, Mr. Sheldon, and $\mathrm{Mr}$. Weston may disagree from him in minor matters, his views are decisive in the management, and the policy of the whole movement depends on him. Through his indefatigable zeal in the holy cause of ethics, his unflinching courage in the defense of what he regards as right, his energetic devotion to his ideals, and through the influence of his powerful oratory he has made the ethical societies what they now are. He determines their character and he is the soul of the whole movement. Now it is true that Professor Adler has never presented us with a systematic philosophy, but all his activity, his speeches, his poems, and the plans of his enterprises represent a very definite philosophical conception, which, to give it a name, may briefly be called Kantian Agnosticism.

Professor Adler is an agnostic, although not after the pattern of Spencer or Huxley. His agnosticism has been impressed upon his mind by Kant.

I expect that Mr. Adler will repudiate the name of agnostic, and it is quite indifferent with what name he may characterise his views. His position remains the same, whatever name he may choose 
to call it, if he chooses any; and he will choose none for he is too consistent an agnostic to define his position by a name.

It devolves upon me to prove my assertion and I hope to be able to do so.

Professor Adler looks upon ethics as something which lies outside the pale of human knowledge. He says in one of his lectures:

"And now one point more of utmost importance. If there be an existence corresponding to our highest idea, as we have said there is, yet we know not what kind of existence that may be. . . . why then should we speak of it at all, why should we try to mention in words an existence which we cannot know? I will answer why. Because it is necessary to remind mankind constantly that there is an existence which they do not know. . . . Because otherwise the sense of mystery will fade out of human lives. ...."

Is "the sense of mystery" really a necessary element in human lives to make men aware of the grandeur of the universe. Is there no holiness in clearness of thought, and is ethics only sacred if it is surrounded with the hazy halo of an unknowable transcendentalism?

If our moral ideal does not come by the special revelation of God, as the dogmatic religions maintain, and if we cannot find it in nature, if it is beyond the ken of human cognition, if it is unascertainable by science, whence does it come? Professor Adler says:

"We must, indeed, be always on our guard, lest we confuse the idea of the Perfect with notions of the good derived from human experience. This has been the mistake of theology in the past, the point wherein every theodicy has invariably broken down. When we think of the Perfect we think of a transcendental state of existence, when we think of the moral law in its completeness we think of a transcendental law, a law which can only be wholly fulfilled in the regions of the Infinite, but which can never be fully realised within the conditions of space and time. The formula of that law when applied to human relations, yields the specific moral commandments, but these commandments can never express the full content, can never convey the far off spiritual meanings of the supreme law itself. The specific commandments do, indeed, partake of the nature of the transcendental law, they are its effects. The light that shines through them comes from beyond, but its beams are broken as they pass our terrestrial medium, and the full light in all its glory we can never see."

In this passage I believe to recognise the influence of Kant's transcendentalism. I differ from Professor Adler's conception of Kantian transcendentalism, but that is of no account here. One 
point only is of consequence. Professor Adler uses the word transcendental in the sense of transcendent and thus he changes the ethics of pure reason into mysticism. Professor Adler says:

"Though I can never be scientifically certain, I can be morally sure that the mystery of the universe is to be read in terms of moral perfection."

I do not deny that moral instinct ripens quicker than scientific comprehension. Why? Because in a time when science is not as yet so far advanced as to understand the operations of the moral law, those people who instinctively obey the rules that can be derived from the moral law, will survive and all the rest will go to the wall. But the fact that we can have a reliable moral guide in an instinctive certainty which is generally called conscience, even before we attain to scientific clearness, does not prove that science will be forever excluded from the world of moral ideals.

Professor Adler's agnosticism found a very strong expression in a poem which resembles in its tone and ideas the church hymns of the New Jerusalem. The poem is very unequivocal on the point that moral action is comparable to building an ideal city, the plan of which is unknown to the builders. Professor Adler says :

\section{"Have you heard the Golden City Mentioned in the legends old? \\ Everlasting light shines o'er it, Wondrous tales of it are tola.}

Only righteous men and women

Dwell within its gleaming wall :

Wrong is banished from its borders, Justice reigns supreme o'er all.

Do you ask, Where is that City, Where the perfect Right doth reign?

I must answer, I must tell you, That you seek its site in vain.

You may roam o'er hill and valley. You may pass o'er land and sea, You may search the wide earth over,' $T$ is a City yet to be! 
We are builders of that City,-

All our joys and all our groans

Help to rear its shining ramparts;

All our lives are building-stones.

\section{What that plan may be we know not."}

How the seat of Justice high,

How the City of our vision

Will appear to mortal eye,-

That no mortal eye can picture,

That no mortal tongue can tell.

We can barely dream the glories

Of the Future's citadel."

How great an importance is attributed to this song by the leaders of the ethical movement may be learned from Mr. Salter's opinion of it. Mr. Salter says in criticising Unitarianism :

"Not from Unitarianism, not from Christianity, has come the song that best utters and almost chants this thought [of an ideal fellowship]. It is from Felix Adler, upon whom, I sometimes think, more than upon any other man of our day, the mantle and prophetic spirit of Channing have fallen, and whose words, I almost believe, are those which Jesus himself would utter, should he come and put his solemn thought and passion into the language of to-day."

Agnosticism is in our opinion no sound basis upon which to erect ethics. The unknowable is like quicksand, it gives way under our feet. The ethics of agnosticism must necessarily become mysticism. The ethereal dreams of mysticists need no solid basis, they hover in the air. Mr. Spencer who for some reason or other tried to escape the consequences of his agnosticism in the ethical field, adopted Utilitarianism, basing his moral maxims not upon the unknowable, as consistency would require, but upon the principle of the greatest happiness for the greatest number.

Professor Adler is not a Spencerian agnostic and here lies the strength of his ethics. Although he does not attain to a clear and scientific conception of the origin and natural growth of morality, he sounds no uncertain voice with regard to the Happiness Principle.

* The italics are ours. 
He has on several occasions, like his great master Kant, uncum. promisingly rejected any Hedonism or Eudæmonism. Among all societies aspiring to foster moral ideals, the societies for ethical culture are distinguished for their seriousness and ardor; and there can be no doubt about the cause : it is the spirit of Professor Adler's zeal not to give way to a hedonistic conception of ethics.

\section{THE UNITY OF THE ETHICAL PROBLEM.}

We conclude. Although the ethical problem can and must be split up in innumerable different problems, we should never lose sight of its unity.

Our age is a period of specialisation, of a division of labor and of detail work. This is true. But the more will it be necessary to survey the whole field and keep in mind the unity of which all piecemeal efforts are but parts. As soon as we lose sight of the unity in a certain system of problems, we are most liable to drop into inconsistencies. This is true of all things, of every science in particular, and of philosophy, the science of the sciences, also. It is no less true of ethics. We cannot engage, with any hope of success, in any of the diverse ethical questions unless we have first solved the ethical problem.

EDIToR. 